\title{
Léxico e cultura: a visão amazônica na obra poética de João de Jesus Paes Loureiro
}

\author{
Lexicon and culture: the Amazonian vision in the poetic work of João de Jesus Paes \\ Loureiro \\ Elis de Almeida CARDOSO* \\ Universidade de São Paulo (USP) \\ Raphael Bessa FERREIRA** \\ Universidade do Estado do Pará (UEPA)
}

\begin{abstract}
RESUMO: Neste artigo, no qual estabelecemos uma interface entre a lexicologia, a estilística e a sociolinguística, pretendemos mostrar de que forma as escolhas e criações lexicais de João de Jesus Paes Loureiro revelam a visão de seu "mundamazônico". Por meio de uma amostragem de sua obra poética, verificamos como o escritor apresenta a cultura amazônica, valorizando tanto os costumes e as lendas, como a força da natureza, principalmente das águas, presentes na vida e na linguagem do homem dessa região, mas também criticando seus principais problemas, tais como a exploração predatória do solo e do homem. Transcendendo a linguagem banal e cotidiana da comunicação rumo a uma dimensão simbólica do homem amazônico, Paes Loureiro cria com sua poesia um espaço reflexivo, expondo a seu leitor elementos constitutivos do contexto amazônico (linguagem e temas sociais, históricos e culturais), na medida em que apresenta seu locus.
\end{abstract}

PALAVRAS-CHAVE: Paes Loureiro. Amazônia. Cultura. Léxico.

\begin{abstract}
In this paper, establishing an interface between lexicology, stylistics and sociolinguistics, we intend to show how the lexical choices and creations of João de Jesus Paes Loureiro reveal the vision of his "mundamazônico". In his poetic work, we see how the writer presents the Amazonian culture, valuing both the customs and legends, as well as the force of nature, especially the water, present in the life and language of man in this region, but also
\end{abstract}

\footnotetext{
* Professora associada do Departamento de Letras Clássicas e Vernáculas da Faculdade de Filosofia, Letras e Ciências Humanas da Universidade de São Paulo. Doutora e Livre-docente em Letras. E-mail: elisdacar@usp.br

${ }^{* *}$ Doutor pelo Programa de Pós-graduação em Filologia e Língua Portuguesa pela Universidade de São Paulo. Professor Assistente IV (TIDE) da área de Literatura do Departamento de Língua e Literatura da Universidade do Estado do Pará. Líder do Grupo de Pesquisa em Linguagens Artísticas e Estilos Poéticos (LAESP). E-mail: ru-98@ hotmail.com
}

Revista Moara, n. 54, ago-dez 2019 ISSN: 0104-0944

Recebido em 16/09/2019

Avaliado em 13/11/2019 
criticizing its main problems, such as predatory exploitation of soil and man. Transcending the banal and everyday language of communication towards a symbolic dimension of the Amazonian man, Paes Loureiro creates with his poetry a reflective space, exposing to the reader constitutive elements of the Amazonian context (language and social, historical and cultural themes).

KEY WORDS: Paes Loureiro. Amazon. Culture. Lexicon.

\section{Introdução}

Sendo o léxico o conjunto organizado de signos para a categorização e nomeação da realidade, é ele o responsável pelas associações de sentidos, pelo resgate de valores, pela ampliação e reorganização dos significados. Por isso, o compósito léxico reflete tanto as mudanças dos sistemas sociais, quanto linguísticos em que residem os fatos culturais servidos pelos usos lexicais e os fatos da língua que são definidos pelos acontecimentos culturais. A palavra é, pois, um instrumento de compreensão social, afirma Matoré (1953), e reflete nossas ideias e nossa visão de mundo.

O objetivo deste artigo é mostrar de que forma as criações e as escolhas lexicais do poeta paraense João de Jesus Paes Loureiro (1939-) se relacionam à cultura e ao contexto amazônico. O pensamento do autor dialoga com a natureza, com os mitos, com as crenças e com o imaginário nativo da região.

João de Jesus Paes Loureiro marca seu lugar devido à forma com que apresenta, ao longo de sua obra, novas perspectivas para discutir, representar e repensar a região amazônica. $\mathrm{O}$ autor não intenta particularizar um locus já muitas vezes estereotipado por outros escritores, que usualmente extraem de uma vivência popular caracteres comuns ao texto literário - tais como a utilização de marcas da oralidade do falante nativo, as descrições de costumes e crenças de um povo ou mesmo o enaltecimento ufanista da natureza local com ares que remetem às tendências românticas -, mas tenta redimensionar a representação da realidade, revelando uma atividade por ele cunhada como "encantaria da linguagem" (PAES LOUREIRO, 2008b, p.7), cujo mérito é trazer para sua poesia algo que ultrapasse a mera descrição "pitoresca" da região, em busca de uma visão mais universal. 
Em seu fazer poético, Paes Loureiro estabelece um espaço reflexivo, tanto no plano da expressão ou da forma, quanto na compreensão dos múltiplos sentidos expressos nas relações significativas do jogo entre as palavras (plano do conteúdo). Transcendendo a linguagem banal e cotidiana da comunicação rumo a uma dimensão simbólica do homem amazônico, o poeta traz à tona tanto sua realidade, quanto as lendas de sua região.

Seus Cantares Amazônicos ${ }^{1}$, que reúnem Porantim, de 1979, Deslendário, de 1981, e Altar em Chamas, de 1982, bem como suas demais obras, aproximam o leitor não só da natureza e das lendas mas também do abandono social do povo amazônico, questionado pelo poeta que denuncia problemas e conflitos da região. De forma crítica, o "desenvolvimento" da Amazônia é visto pelo autor como um processo políticotransformacional que corrói o mundo ancestral de mitos, lendas e fantasias (o imaginário cultural amazônico), levando à perda das tradições e dos costumes locais.

Por meio da análise das palavras escolhidas e criadas por Paes Loureiro, recolhidas de sua obra poética, o presente artigo tem, então, por objetivo mostrar de que forma aspectos culturais e sociais da Amazônia, bem como seus mitos e lendas, são revelados por meio do léxico, em uma tentativa de unir essa parte dos estudos linguísticos tanto à estilística quanto à sociolinguística.

\section{A amazonicidade de Paes Loureiro}

Embora apresente valores universais, a obra poética de Paes Loureiro gira em torno de temáticas íntimas à realidade da Amazônia, justamente por questionar eventos socioeconômicos provenientes da exploração da região. Ao tomar emprestadas temáticas particulares e afins à sua região, o poeta se vale do uso de um léxico amazônico, com o objetivo de reconstruir na experiência da poesia uma consciência crítica sobre os problemas desse locus. Segundo Nejar (2011, p. 973), "Loureiro cria sua própria arqueologia mitológica, em linguagem simples, por vezes repetida, com metáforas famintas, penetrando na floresta e seu mundo elementar".

A opinião de Nejar pode ser atrelada a uma corrente que caracteriza a poesia loureiriana apenas pelo ponto de vista do regional, do local, em que os elementos

\footnotetext{
${ }^{1}$ Cantares Amazônicos integra o volume 1 das Obras reunidas, de João de Jesus Paes Loureiro (São Paulo: Escrituras Editora, 2000).

Revista Moara, n. 54, ago-dez 2019 ISSN: 0104-0944

Recebido em 16/09/2019 Avaliado em 13/11/2019
} 
culturais pertencentes ao eixo do léxico e dos temas discutidos sublinham toda a poética do autor. Contudo, de acordo com o próprio Paes Loureiro (2012, p.21), a Amazônia pode ser conceituada e discutida poeticamente, tendo em vista a produção do pensamento e de arte na região.

Na sociedade amazônica é pelos sentidos atentos à natureza magnífica e exuberante que o homem se afirma no mundo objetivo e é por meio deles que aprofunda o conhecimento de si mesmo. Essa forma de vivência, por sua vez, desenvolve e ativa a sensibilidade estética. Os objetos são percebidos na plenitude de sua forma concreto-sensível, forma de união do indivíduo com a realidade total da vida, numa experiência individual que se socializa pela mitologia, pela criação artística, pelas liturgias e pela visualidade (PAES LOUREIRO, 2012, p.21).

Essa força ativa do amazônida sob a natureza é mote do autor paraense tanto para as suas reflexões ensaísticas, que discutem a amazonicidade, quanto para os seus trabalhos poéticos, que promovem o que Lucas (2012), em análise da produção de Paes Loureiro, chama de passagem do banal para o artístico.

João de Jesus Paes Loureiro, a cada obra, foi dominando cada vez mais a arte do fazer literário, a ponto de, muitas vezes, refletir sobre a inocuidade da voz do poeta ante a transformação da Amazônia num território conflagrado. A consciência, portanto, reflete a posse dos meios de expressão, a técnica literária propriamente; e a tal ponto que o poeta se permite ter como referente ora o desconcerto do mundo, ora a força da poesia ao denunciar os desacertos, seguida de sua fragilidade em promover mudanças (LUCAS, 2012, p.121-122).

Pode-se dizer, então, que João de Jesus Paes Loureiro clama à sua produção estética um meio de expressão dos elementos constitutivos do contexto amazônico (linguagem e temas sociais, históricos e culturais), na medida em que reflete sobre um novo mundo, um "mundamazônico", como ele prefere. Esse mundo poético que espelha a Amazônia é, para Fontes (2001, p. 9), a revelação de determinadas potências perceptíveis na escrita do autor: 
se existe uma lei arregimentando as imagens que percorrem o texto como cometas, demônios em fúria ou anjo exterminador, ela é a que rege a própria arte poética de João de Jesus Paes Loureiro: a submissão do enunciador a todas as potências do ritmo - verbal, cósmico, amoroso.

Desse modo, há de se concordar com Ianni (2001), que estabelece uma série de questões pontuais quando o assunto diz respeito aos traços poéticos do autor:

\footnotetext{
é uma escritura fluindo como se fosse oralidade, a despeito das exigências da literalidade; nascendo de estórias e lendas, casos e mitos, assombrações e alucinações. A beleza da escritura leva consigo o encanto da oralidade, o que conta, canta e encanta, conferindo outras luzes ao que se lê, como se olhasse e ouvisse (IANNI, 2001, p.10).
}

Pode-se dizer que a situação do amazônico em Paes Loureiro ultrapassa o mero cultivo de imagens regionais. Nas palavras de Benedito Nunes (2009), o poeta vai além, exteriorizando as particularidades locais para implantar a linguagem poética como tema de sua produção estética: "Extensa e caudalosa, como extenso e caudaloso é o rio Amazonas, corrente de linguagem por ela percorrida, e em que vão de bubuia versos ressonantes, acústico-visuais" (NUNES, 2009, p.17).

\section{O locus amazônico indígena nas escolhas e criações lexicais de Paes Loureiro}

A região amazônica figurativiza-se, lexicalmente, na obra poética de Paes Loureiro. Indigenismos se mesclam a expressões populares e vocabulário regional, valorizando o universo linguístico do homem daquela paisagem geográfica. Essa experiência de aliar o local ao fazer poético pode limitar-se ao regional, recaindo apenas na representação de um locus como essência da poesia. O diferencial, entretanto, está no trato da linguagem em situação diferenciadora, tornando-a protagonista e universalizante. O poeta Manoel de Barros afirma que "nossas particularidades só podem ser universais se comandadas pela linguagem. Subjugadas por um estilo" (BARROS, 1992, p.334).

Revista Moara, n. 54, ago-dez 2019 ISSN: 0104-0944 
A produção literária amazônica evidencia o processo formador cultural do homem da região, historicamente miscigenado e em contínua interação entre raças e povos díspares, e não menos de línguas intrínsecas e extrínsecas entre si (como o tupi e seu derivado tupi-guarani, bem como o nheengatu).

Para Souza (2012),

É essa necessidade de se entender que origina a possibilidade de um novo léxon, verbetes oriundos de cada etnia, empréstimos, deturpações, acréscimos linguísticos inter-raciais interagem, e o círculo vicioso acontece: podem perder-se ou podem ultrapassar fronteiras, assim como podem incorporar verbetes do tronco europeu adulterando sua figura de linguagem (SOUZA, 2012, p.12).

Em relação às escolhas lexicais feitas pelo poeta, percebe-se que é constante a utilização de indigenismos que pertencem ao léxico do habitante da região amazônica. Chamados de palavras evocativas por Bally (1951), os indigenismos nos remetem a um lugar e a um meio social e cultural.

Em Altar em Chamas (2000), por exemplo, o autor explora unidades lexicais indígenas, tais como "Icamiabas", "Chincoãs", "Cunhantãs" e mesmo palavras pertencentes ao mundo mágico do imaginário popular amazônida, como "Yara" e "Boiúna".

Em "Paisagem Recordada" (Altar em chamas), o autor aglomera em dois versos elementos do léxico cultural do caboclo amazônico:

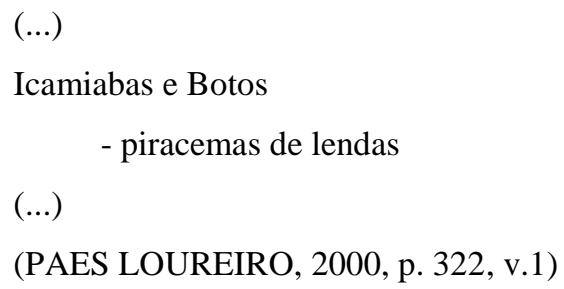

As "Icamiabas", índias guerreiras que se correlacionam historicamente ao mito das amazonas - mulheres guerreiras -; os "botos", personagens de lendas do imaginário cultural da região; e a "piracema", o nome dado ao movimento migratório dos peixes no 
rio, aparecem, no poema, proporcionando ao leitor conhecimentos do contexto e da realidade amazônica.

Exemplo desse estilo que mescla regional e universal, tecendo ainda paralelos intertextuais de campo semântico ligado à amazonicidade, pode ser constatado no poema "Cântico XLII" (Porantins) em que uma série de compostos criados pelo poeta se investem da relação mítica:

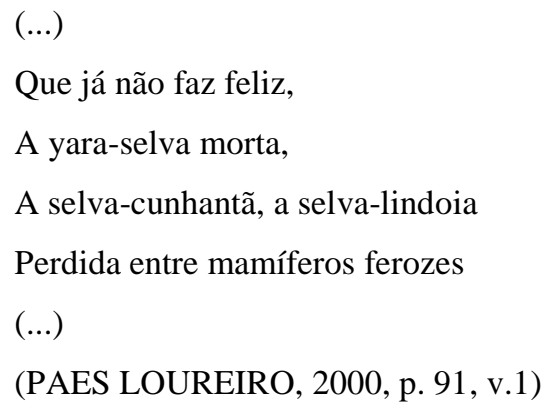

Em "yara-selva" a ocorrência de uma base de etimologia tupi, "yara", que contém valor semântico mítico-folclórico e, ao mesmo tempo, o indicativo de feminilidade (Yara é símbolo da entidade feminina protetora da natureza e a grande mãe da mata virgem), confere à criação lexical um verdadeiro leque de interpretações peculiares. A floresta, antes virgem, intocada e protegida, é agora destituída de sua primitiva originalidade, pois jaz "morta" e corrompida. Ressalta-se ainda que, na mitologia amazônica, a Yara, ou Iara, apresenta-se também como um coletivo de seres fantásticos protetores das águas e das riquezas amazônicas, sendo "guardiãs dos minérios ainda intocados no fundo das águas e nas camadas inferiores das terras amazônicas" (SOUZA, 2012, p.92).

A mesma relação semântica é percebida em "selva-cunhantã", que agrega à base designadora do locus silvestre por excelência ("selva") o também indigenismo "cunhantã”, que designa a mulher jovem e ainda menina. Em relação analógica com "yara-selva", a "selva-cunhantã" representa ainda uma ideia de inocência do ambiente selvagem, ainda não tocado pelas mãos cobiçosas do homem (SOUZA, 2012, p.68).

Por fim, "selva-lindoia" refere-se, em sua base determinante, a uma personagem da literatura brasileira, Lindoia, oriunda da obra O Uraguai, de Basílio da Gama. Na epopeia árcade, a personagem feminina deixa-se picar por uma cobra venenosa no 
intuito de manter-se honrada ao evitar o assédio de um maldoso jesuíta, responsável pela morte de Cacambo, o cacique com o qual era casada. Lindoia representa a bravura e vitalidade da natureza feminina. Tal nome representa, ainda, o sacrifício diante da perda da fidelidade do amor.

Desse modo, intensificando o derradeiro suspiro da natureza, os neologismos são providos de valores intensivos, num crescente semântico que passa pelas fases infantil ("cunhantã"), jovial ("lindoia") e adulta ("yara") até o culminante estado de aniquilamento, pois a selva agora jaz "Perdida entre mamíferos ferozes" (seres humanos destruidores).

A Amazônia se revela nos versos do poema com toda uma série de elementos lexicais que representam não só o contexto social local, mas também o cultural, o linguístico, o mítico e mesmo o histórico e o econômico, tendo em vista que o poema retrata a destruição de um universo virginal, a floresta, pelo explorador branco, seja ele representado na figura do colonizador ou mesmo dos grandes empreendimentos do mercado.

\section{O mudo das águas: a linguagem-rio}

Pode-se dizer que a poesia de Paes Loureiro possui sua força motriz a partir da visão de mundo do autor, e que os seus sentimentos (sejam eles axial, teológico, metafísico ou existencial) emergem na temática de seus poemas.

Nem topos, nem símbolo, nem leitmotiv, mas sim "tema", terminologia profundamente consistente com um conceito íntimo ao sentido/sentimento do "eu" para com a obra de arte e que acaba por imbricar no todo construído que é a arquitetura poética.

Podemos destacar, sob essa perspectiva, que o elemento da maioria das reflexões poéticas do autor reside em temas ligados ao rio: seja em sua personificação enquanto ser nativo da região amazônica, seja enquanto espelho que reflete o existir do poeta, seja enquanto recurso metapoético para os questionamentos acerca da criação de poesia. $\mathrm{O}$ rio, na obra de Paes Loureiro, é, segundo Oliveira (2003, p.44):

o lugar onde o paradigmático tem seu endereço. Perfeição configurada como pureza, beleza idílica, inocência. [...] A arregimentação do poeta em caracterizar o rio como um problema ontológico, é metafísica. Certo é que o 
autor não deseja ensejar esse debate; deseja, sim, arar o terreno em que seus temas mais candentes serão plantados. O poema trabalha com o rio e o desconhecimento de sua condição.

Como um work in progress, as discussões poéticas do autor sobre o rio compõem não apenas a temática de sua poesia, como também ensejam reflexões da relação existente entre forma e conteúdo empregados, de modo que dialoguem entre si no poema.

Exemplo disso pode ser visto no poema "Busquei", que integra o livro Água da Fonte (2008a):

\author{
Busquei no olho d'água \\ a primeira palavra \\ e a língua represada em sua fonte. \\ Busquei no canto \\ em língua submerso \\ o verso essencial. \\ Só o poema resgata \\ em líquidos abismos \\ a primeira palavra \\ o peso do passado \\ e todos os tesouros de fonemas \\ que a jusante sepulta pela foz.
}

No leito do poema

encantarias brotam das palavras

quando o rio se põe a cantar.

(PAES LOUREIRO, 2008a, p.155)

O enunciador se coloca em contato com o mundo amazônico, com a natureza e a paisagem da região, mesclando a essa visão paradisíaca certo tom metalinguístico, visto que o poeta procura a palavra "encantada". O "verso essencial", submerso na língua encantada, é também a "primeira palavra", ainda "represada em sua fonte", momento 
primordial ao poeta, que busca "no olho d'água" encontrar os "tesouros de fonemas", ou seja, o autor poetiza o que há de amazônico no contexto do poema.

O conteúdo dos versos discute o contexto local, assim como o plano da expressão faz reverberar as malhas hídricas dos rios da região, que se mostram nos versos dispersos no espaço gráfico da página (com estrofes quebradas e dispostas à esquerda e à direita sem padrão de agrupamento formal). A desagregação espacial dos versos se assemelha ao movimento das ondas, das marés e das cheias e vazantes dos rios amazônicos, em versos deslocados pela página como se fossem canoas. Por isso que o rio, símbolo da paisagem amazônica por excelência, é motivo de elucubrações por parte do autor:

\footnotetext{
O próprio homem da terra, ao penetrar no emaranhado dos rios - que se interligam, se estreitam, se alargam, mudam de cores e profundidades, exibem e escondem perigos - desse mundo que parece não ter fim, se dá conta do real enquanto uma vaga forma de imensidão que se confunde com o imaginal (PAES LOUREIRO, 2015, p.115).
}

A técnica empregada no poema reflete o estilo do escritor, que se vale das noções poéticas para enfatizar um projeto questionador da própria linguagem poetizada, o que acaba por constituir uma obra de formato labiríntico - como os rios e a vegetação amazônica -, na expansão da poesia em si.

Submetendo a língua a uma densa carga de afetividade e de expressividade, Paes Loureiro lança mão de sua criatividade lexical, tanto pelo uso de neologismos, quanto de metáforas, recriando um mundo pela arte da palavra, o "mundamazônico".

Em "A hora da poesia" (Artesão das águas ${ }^{2}$ ), o rio é visto com um espelho de memórias pelo qual o poeta navega e se arrisca:

Eis-me diante de um rio

retângulo corrente

espelho de memórias

caminho já por tantos navegado.

Onda após onda

\footnotetext{
${ }^{2}$ O livro Artesão das águas integra o volume 2 das Obras reunidas, de João de Jesus Paes Loureiro (São Paulo: Escrituras Editora, 2000).

Revista Moara, n. 54, ago-dez 2019 ISSN: 0104-0944

Recebido em 16/09/2019

Avaliado em 13/11/2019
} 


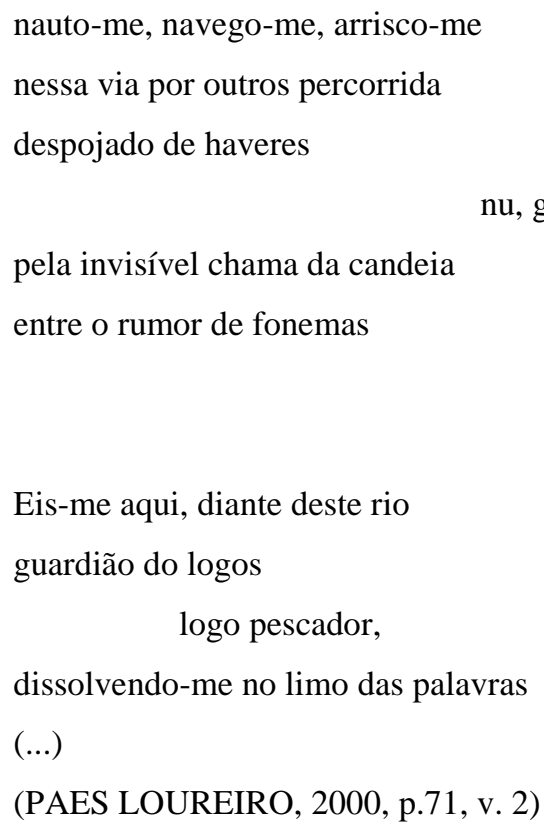

A relação poesia/rio aparece no poema equiparada à relação linguagem/água. $\mathrm{O}$ poeta busca a linguagem poética submersa no rio da linguagem - "Eis-me diante de um rio/retângulo corrente"- colocando-se como um pescador, um ribeirinho ou um observador que vive às margens das águas. As águas, por sua vez, guardam a palavra, que pode ser escorregadia como o limo em que o poeta se dissolve.

Os neologismos literários "apresentam marcas individuais, mas não podem ser distanciados do quadro social. A expressividade só pode ser compreendida, levando-se em consideração sua relação com a frase, o texto, o discurso" (CARDOSO, 2018, p.190).

Nos poemas pertencentes ao ciclo dos Cantares Amazônicos, são nítidos inúmeros processos estilísticos de criação neológica. Tais recursos tornam-se eficazes na valorização do campo lexical ligado à amazonicidade. As novas unidades lexicais oriundas dos processos de composição e derivação demonstram parte de toda uma cosmovisão da realidade amazônica, revelando a visão de mundo do autor. A relação com o rio pode ser vista com a criação de unidades lexicais neológicas como amazonar e maroceano, encontradas no "Cântico III" (Porantim): 


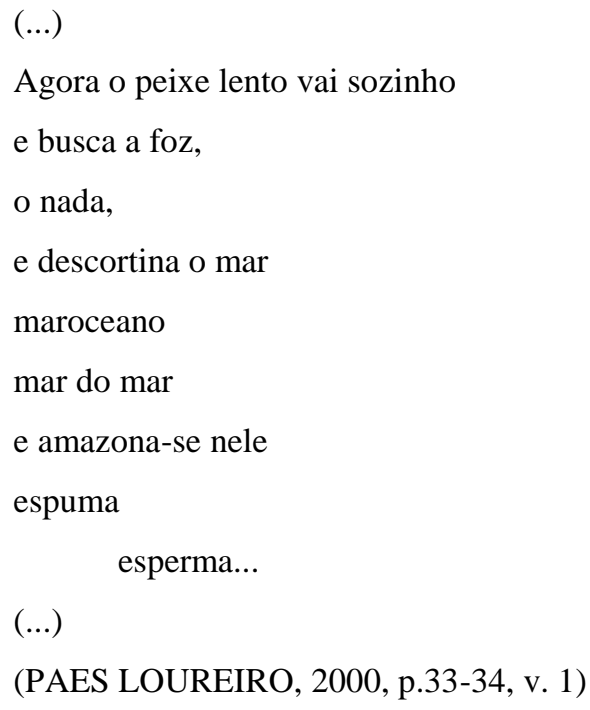

O estilo do poeta, portanto, se pauta não somente pela incorporação de unidades lexicais de origem e uso recorrentes na região amazônica, mas também pela tendência em explorar criativamente os recursos da língua. A "paisagem" literária criada a partir do repertório linguístico do autor aponta a organização de toda uma operação de criação poética. Assim, a obra de arte não somente revela a expressividade do artista, como também problematiza o trato deste com a linguagem, matéria comunicativa que o põe em diálogo consigo e com o mundo.

Pode-se dizer, com isso, que a "linguagem-rio" que o poeta tanto aborda em sua obra representa a aliança entre o conteúdo temático de seus poemas com o formato poético de sua criação. A linguagem deixa de ser usual, cotidianizada e comum para tornar-se encantada, mágica e preenchida com cargas semânticas diferenciadas, que inovam os sentidos questionadores da realidade amazônica.

A simbiose homem/natureza funda uma visão estética sobre a Amazônia e tudo o que lhe é inerente: cultura, realidade social, histórica, econômica etc. A integração entre essas visões dissipa os contrastes e faz emergir do artístico uma realidade "encantada", em que o poético emerge do cotidiano do ribeirinho, do caboclo e dos demais sujeitos viventes na região. Daí o rio, imagem arquetípica deste locus, ser elemento imprescindível ao poeta em sua recriação da realidade pela criação de poesia. 


\title{
4. Lendas da Amazônia
}

As lendas brasileiras vivem nas memórias coletivas e são repetidas de geração em geração. Seres folclóricos povoam o imaginário popular e fazem parte do cotidiano de muitas comunidades. Na Amazônia, local de muita miscigenação, é comum o perpetuar de histórias como a da boiúna e a do boto. Esses habitantes dos rios da floresta ganham um quê de divino e sobrenatural, chegando a adquirir traços humanos. A boiúna, também conhecida por Cobra Honorato ou Norato, é a cobra grande da Amazônia, cujo habitat é as profundezas dos rios ou dos lagos. Conta a lenda que a cobra-grande pode se transformar em embarcações ou outros seres, até mesmo em ser humano. O boto, típico dos rios amazônicos, é considerado amigo dos pescadores da região. De acordo com a lenda, ele auxilia os pescadores e conduz as embarcações durante chuvas fortes. Tem o poder de se transformar em um lindo moço que seduz as donzelas, engravidando-as em noites de festa.

Paes Loureiro traz para sua obra poética as lendas da Amazônia, algumas vezes para valorizar o seu locus, outras vezes para mostrar que as lendas podem deixar de existir, se aspectos sociais e culturais não forem preservados.

O poema "A história luminosa e triste do Cobranorato" (As encantarias ${ }^{3}$ ) dialoga com a lenda da Cobra-grande, ou Boiúna, figura à qual é atribuída a paternidade de crianças filhas de moças "encantadas" por esse ser mágico:

\author{
E desde então dessa hora, \\ tempo outrora, nosso tempo, \\ todo filho que nascia

\footnotetext{
${ }^{3}$ O livro As encantarias integra o volume 2 das Obras reunidas, de João de Jesus Paes Loureiro (São Paulo: Escrituras Editora, 2000). 
Imputando a uma figura lendária a responsabilidade por uma gravidez indesejada, o poema apresenta um jogo de ambiguidade expresso pelo paradoxo "mentiramente verdade". De forma irônica, as paternidades desconhecidas são atribuídas a Honorato: "todo filho que nascia / de amor que ninguém sabia / era filho de Honorato".

Esse ser folclórico, mestiço de homem e cobra, à noite assume sua forma humana ao sair dos rios e conviver com os nativos da região. Nas lendas amazônicas, Honorato passa, em um determinado momento de sua vida, a ser de uma vez por todas um ser humano, abandonando seu lado mítico selvagem para ganhar ares humanizados, “desencantando-se", portanto.

Já no poema "Deslenda narcísica do boto III" (Deslendário ${ }^{4}$ ), o personagem folclórico que dá título ao poema (o boto) perde o seu caráter mágico e o poder de encantar, por sua beleza, as ribeirinhas que se apaixonavam por ele:

\footnotetext{
Ater-se à só beleza lídima das lendas eis o risco.

Deslendado boto, desnarciso.

Haver de ater-se além das aparências

E mergulhar nos desconfins do ser

(PAES LOUREIRO, 2000, p.124, v.1)
}

O boto é destituído de sua aura encantatória, tornando-se um "deslendado boto", no momento em que lhe são subtraídos sua beleza e seus encantos. Lembrando o mito grego, o poeta compara a beleza do boto, quando homem, com a de Narciso. Na criação neológica "desnarciso", o prefixo des- une-se ao substantivo "narciso", que faz referência não apenas ao ser mitológico, como também à planta de mesmo nome, cuja característica é a ligeira inclinação da postura de seu caule, assemelhando-se à fisionomia do boto (em posição oblíqua). "Deslendando-se", o boto se "desnarcisa".

No poema "Deslenda Rural V" (Deslendário), a crítica do poeta é evidente. Ao trazer para o texto os "grandes proprietários", os "advogados de ouro", os "jagunços" e

\footnotetext{
${ }^{4}$ O livro Deslendário integra o volume 1 das Obras reunidas, de João de Jesus Paes Loureiro (São Paulo: Escrituras Editora, 2000).

Revista Moara, n. 54, ago-dez 2019 ISSN: 0104-0944 
os "pistoleiros", Paes Loureiro deixa claro que, ao morrer o homem amazônico, morrem as lendas. "botos", "uiaras" e "curupiras" deixam, portanto, de existir.

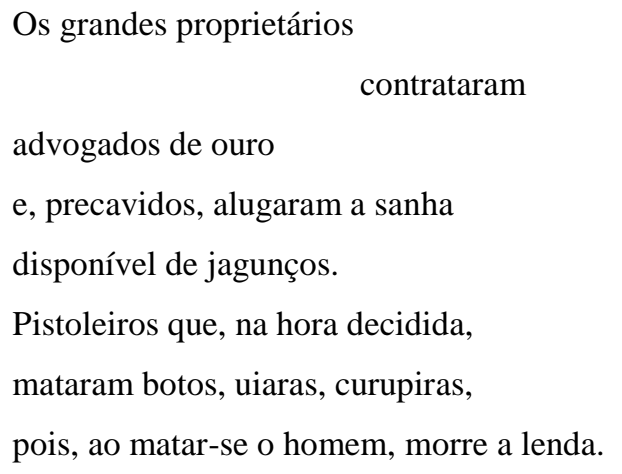

(PAES LOUREIRO, 2000, p.160-161, v.1)

Nota-se que as figuras lendárias do imaginário amazônico são confrontadas com outros protagonistas em um cenário de luta. Os responsáveis pela problemática dos conflitos agrários na região, como "pistoleiros" e "jagunços" subordinados aos mandos dos "grandes proprietários", compõem o cerne da discussão sobre a morte no campo.

\section{Conflitos amazônicos: as deslendas}

Notícias sobre a destruição da Amazônia estão na ordem do dia. As queimadas que consomem a floresta, dando lugar a plantações e pastos, o desmatamento ilegal e predatório, as mortes de líderes e ativistas, a invasão de terras indígenas, as políticas capitalistas e exploratórias, a falta de recursos para a população local, dentre outras questões estão no foco da imprensa nacional e internacional.

De acordo com Pinto (2012), a Amazônia é o lugar em que mais se mata pela terra:

[...] em pleno século XXI, conviver com matança de índios, conflitos pela terra, trabalho escravo, prostituição infantil, métodos de produção remanescentes à revolução industrial inglesa do século XVIII. O lugar onde mais se mata para ter um pedaço de terra, embora a Amazônia ainda seja um “espaço vazio" do tamanho de dois terços do Brasil (PINTO, 2012, p.29).

A preocupação com seu locus aparece nitidamente na obra poética de Paes Loureiro. No livro Deslendário, muitos poemas abordam temas ligados ao 
desmatamento, à exploração exagerada da terra, seja pelo extrativismo da borracha, seja pela produção agrícola, seja pela mineração. A força do dinheiro é duramente criticada, bem como a ameaça à vida por meio dos conflitos armados.

A escolha de palavras ligadas às questões jurídicas e de ordem agrária, bastante usuais na comunidade amazônica, mostram-se recorrentes em sua poesia. Unidades lexicais muito utilizadas em textos jornalísticos como "posseiro", "grileiro", "jagunço", "pistoleiro", "sem-terra" e "assentamento", que se referem a problemas da região amazônica (e também de outras regiões), aparecem nos poemas loureirianos com o objetivo de criticar e denunciar uma face cruel da Amazônia.

Os rostos da Amazônia são rasgados pelas "monetárias mãos", como afirma o poeta em “Os rostos da Amazônia ou Deslenda rural” (Deslendário):

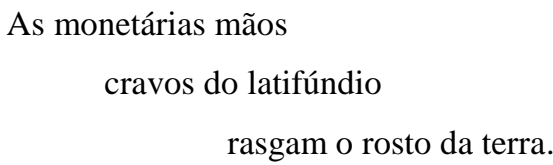

O rosto do homem amazônico, continua o poeta, é um "tristerosto", um rosto escravizado entre os barrancos e os dólares:

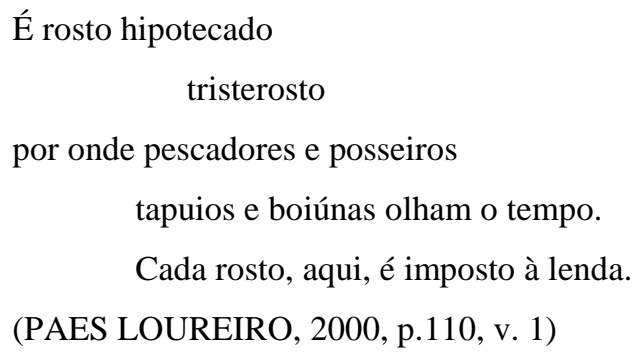


É o rosto do indígena que perde suas terras, o rosto do ribeirinho que sofre com as doenças, o rosto do camponês enganado que vê a grilagem dos seus sítios e a invasão das empresas multinacionais em seu território:

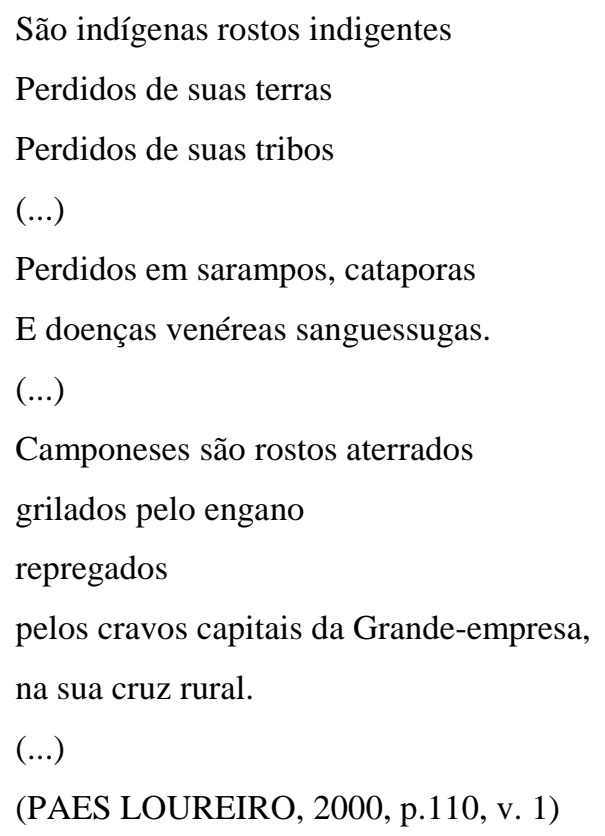

São rostos com medo, rostos que perderam tudo:

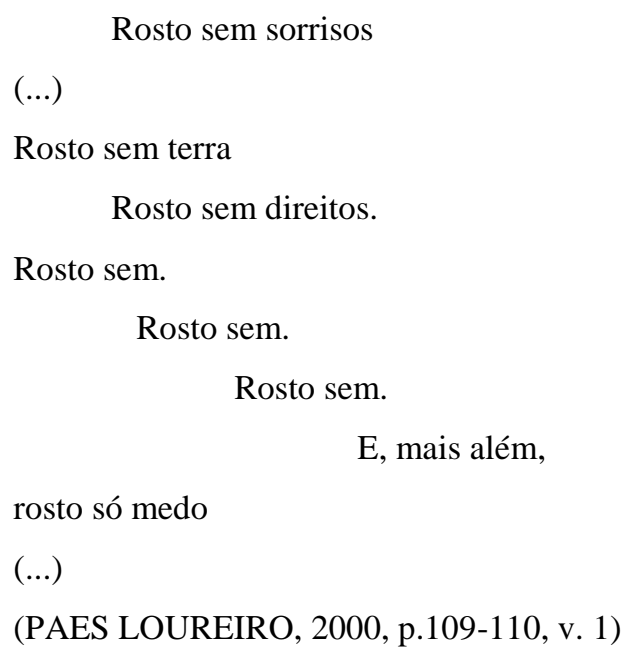

De modo a contestar o destino apocalíptico da região, o autor revela muita preocupação com o seu locus. O trabalho poético clama, então, por uma emergente discussão daquilo que é matéria recorrente na mídia nacional e até mesmo internacional: os temas de natureza social. 


\section{Considerações Finais}

Neste artigo, no qual estabelecemos uma interface entre a lexicologia, a estilística e a sociolinguística, pretendemos mostrar de que forma as escolhas e criações lexicais de Paes Loureiro revelam a visão de seu "mundamazônico".

Por meio de uma amostragem de sua obra poética, verificamos como o escritor apresenta sua Amazônia, valorizando tanto os costumes e as lendas, quanto a força da natureza, principalmente das águas, presentes na vida e na linguagem do homem dessa região, mas também criticando seus principais problemas (suas "deslendas"), tais como a exploração predatória do solo e do homem. Por trás de seu estilo poético, revela-se um posicionamento crítico e questionador. Sua linguagem particular mostra ao leitor aspectos sociais, políticos, geográficos, econômicos e culturais de sua terra natal. A expressividade das escolhas e criações lexicais do autor relaciona-se ao local, em uma busca contínua pelo universal.

Dessa forma, a obra poética loureiriana estabelece um diálogo não apenas com dados históricos, sociais e folclóricos da e sobre a Amazônia, mas também com outros textos canônicos da literatura. O leitor é chamado a penetrar no locus amazônico e a perceber a "encantaria da linguagem" qual um nativo, transformando-se em ser amazônida e vivenciando aquele universo por meio da "linguagem-rio" do poeta.

Para Paes Loureiro, o poema deve atuar "como algo novo em que o conjunto atua como complexidade, onde cada elemento integra e interpreta o todo, na medida em que o todo representa e dimensiona cada parte" (PAES LOUREIRO, 2017, p.249-250).

Com suas criações lexicais, o autor dá ênfase ao campo semântico ligado à água, e a toda a vida ligada a esse universo. Sua poesia está atrelada ao rio, seu fazer poético vincula-se, pois, aos aspectos mágicos e sagrados das águas amazônicas. Como um pescador ou um canoeiro, o poeta devaneia, deixando-se levar "debubuia" pelas águasversos de seus poemas. Sua linguagem-rio confirma que as sílabas, as palavras, as frases, os versos e as estrofes se mesclam a uma reflexão sobre o poético e sobre a Amazônia como se ambos fossem um só: a natureza primeva das coisas, do homem, dos demais seres e da palavra, ainda constituída por sua aura sagrada, encantada, lendada.

Os questionamentos do autor vão além da valorização da exuberante natureza e chegam aos problemas socioambientais e econômicos existentes na Amazônia. O olhar 
crítico do poeta se volta aos conflitos agrários e também aos ataques à natureza antes intocada, revelando seu caráter combativo diante da omissão do poder público em comunidades, assentamentos, glebas e aldeias. Os indigenismos chamam a atenção para a destruição de etnias indígenas e para a importância da preservação das lendas e costumes desses povos amazônicos.

Para o poeta, os avanços exploratórios do mercado destruíram uma concepção primitiva de mundo, de natureza e do convívio do homem com o sagrado, ou com os seres "encantados". Palavras como "deslenda" e "deslendário" denunciam essa triste realidade.

Seres anteriormente imateriais desaparecem, enquanto seres materiais, criados pelo homem, passam a tornar-se "lendas", no processo de desencantamento do mundo. O mundo sagrado do boto e da boiúna é substituído por um mundo profano, monstruoso e destruidor.

Assim, percebe-se que as escolhas de palavras dialogam com o contexto amazônico, valorizando a cultura e chamando a atenção para os problemas por meio de efeitos poéticos. O tom denunciador da obra loureiriana recria um universo culturalmente rico, mas degradado pelo homem e pelo capital. A originalidade por meio do uso das palavras e da criação de novas unidades lexicais faz transparecer uma cosmovisão de Amazônia muito mais detalhada, por conta do efeito estético obtido pela criatividade do poeta.

\section{REFERÊNCIAS}

BALLY, C. Traité de stylistique française. Paris: Klincksiekc, 1951.

BARROS, M. Gramática expositiva do chão - poesia quase toda. Rio de Janeiro: Civilização Brasileira, 1992.

CARDOSO, E. A. O léxico no discurso literário: a criatividade lexical na poesia moderna e contemporânea. São Paulo: EDUSP, 2018.

FONTES, J. B. O feitiço de Varuna. In: PAES LOUREIRO, J.J. Do Coração e suas amarras - cantiga d'amor de refrão. São Paulo: S/E, 2001, p.7-19.

IANNI, O. Lendas do novo mundo - Ensaio sobre a poesia de João de Jesus Paes Loureiro. São Paulo: S/E, 2001. 
LUCAS, F. Peregrinações Amazônicas: História, Mitologia, Literatura. Taubaté: LetraSelvagem, 2012.

MATORÉ, G. La méthode em lexicologie. Paris: Domaine français, 1953.

NEJAR, C. História da Literatura Brasileira - da Carta de Caminha aos contemporâneos. São Paulo: Leya, 2011.

NUNES, B. A clave do poético. São Paulo: Companhia das Letras, 2009. OLIVEIRA, R. Mito e Modernidade na Trilogia Amazônica, de João de Jesus Paes Loureiro. Belém: NAEA, 2003.

PAES LOUREIRO, J.J. Obras reunidas. São Paulo: Escrituras, 2000, volumes 1 e 2.

PAES LOUREIRO, J.J. Água da Fonte. São Paulo: Escrituras, 2008a.

PAES LOUREIRO, J.J. A arte como encantaria da linguagem. São Paulo: Escrituras, 2008b.

PAES LOUREIRO, J.J. Do mito à ciência. In: PAES LOUREIRO, J de J., OLIVEIRA, R. G., DUARTE, R. (Org.) Arte e Cultura na Amazônia: os novos caminhos. Boa Vista: Editora da UFRR, 2012. p.15-25.

PAES LOUREIRO, J.J. Cultura Amazônica - uma poética do imaginário. Belém: Cultural Brasil, 2015.

PAES LOUREIRO, J.J. Encantarias da palavra. Belém: EDUFPA, 2017.

PINTO, L. F. Um mundo em criação (e destruição). In: SCHMINK, M., WOOD, C. H. (Org.) Conflitos sociais e a formação da Amazônia. Belém: EDUFPA, 2012.

SOUZA, H.J. Dicionário amazônico de termos, abusões e verbetes. Manaus: Edua, 2012.

Revista Moara, n. 54, ago-dez 2019 ISSN: 0104-0944

Recebido em 16/09/2019 Avaliado em 13/11/2019 